\title{
Makroinvertebrata sebagai Bioindikator Kualitas Perairan Waduk Batujai di Lombok Tengah
}

\author{
Lalu Achmad Tan Tilar Wangsajati Sukmaring Kalih ${ }^{1 *}$, I Gede Nano Septian ${ }^{1)}$, Denianto Yoga Sativa ${ }^{1)}$ \\ ${ }^{1)}$ Program Studi Pemanfaatan Sumber Daya Perikanan, Fakultas Perikanan, Universitas 45 Mataram, Jl. Imam Bonjol 3, \\ Mataram, Nusa Tenggara Barat, Indonesia \\ *)Alamat korespondensi: tantilar@mail.u45mataram.ac.id
}

\begin{abstract}
ABSTRAK
Waduk Batujai yang terletak di Kabupaten Lombok Tengah merupakan penampung dari beberapa aliran sungai di wilayah tersebut. Hal ini menjadikan Waduk Batujai menjadi tempat akumulasi berbagai bentuk bahan pencemar yang terbawa oleh sungai-sungai inletnya. Pengambilan contoh makroinvertebrata dilakukan dengan menggunakan jala atau jaring dengan ukuran bukaan 30x30 $\mathrm{cm}^{2}$. Selain itu, beberapa parameter fisik dan kimia lingkungan juga diamati seperti suhu, kecerahan, salinitas, da n pH. Analisis data dilakukan untuk mengetahui tingkat kelimpahan, keanekaragaman, dominansi, dan indeks penting biotik. Data hasil analisis diperoleh suatu bentuk kuantifikasi kondisi perairan yang selanjutnya diuraikan secara deskriptif. Makroinvertebrata yang telah teridentifikasi dari hasil sampling dalam penelitian ini sebanyak 495 individu dari 19 spesies dalam 10 famili berbeda. Spesies yang memiliki kelimpahan tertinggi yaitu Anisops breddini. Keberadaan makroinvertebrata yang ada di Waduk Batujai memperlihatkan nilai Family Biotic Index (FBI) sebesar 4,73. Nilai tersebut berada di kisaran 4,26-5,00 dengan kategori kualitas air yang "Baik". Analisis SIGNAL 2 untuk makroinvertebrata Waduk Batujai menunjukkan nilai sebesar 5,73 yang mengkategorikan Waduk Batujai sebagai habitat yang baik.
\end{abstract}

Kata kunci: makrobentik, bioindikator, pencemaran, Waduk Batujai

\section{Macroinvertebrate as Water Quality Bioindicator of Batujai Reservoir in Lombok Tengah}

Lalu Achmad Tan Tilar Wangsajati Sukmaring Kalih ${ }^{1 *}$, I Gede Nano Septian ${ }^{1)}$, Denianto Yoga Sativa ${ }^{1)}$

${ }^{1)}$ Study Program of Fisheries Resource Management, Faculty of Fisheries, University of 45 Mataram, Jl. Imam Bonjol 3,

Mataram, Nusa Tenggara Barat, Indonesia

${ }^{*}$ Email: tantilar@mail.u45mataram.ac.id

\section{ABSTRACT}

Batujai Reservoir located in Lombok Tengah Regency is a reservoir for several rivers in that area. This function makes the Batujai Reservoir as a accumulation place of various forms of pollutants carried by its inlet rivers. Sampling of aquatic macroinvertebrates was done using two combination methods. The macroinvertebrates that were collected were members of Mollusca and Crustacea. Several physical and environmental chemical parameters were also evaluated such as temperature, brightness, salinity, and pH. Data analysis was conducted to determine the level of abundance, diversity, dominance, and biotic important index. Data analysis was then obtained a form of quantification of the condition of the waters which were described descriptively. Aquatic macroinvertebrates that have been identified from the results of sampling in this study were 495 individuals consisted of 19 species from10 families. The highest abundance species was Anisops breddini. Aquatic macroinvertebrates in Batujai Reservoir showed the value of Family Biotic Index (FBI) of 4.73. This value was in the range of 4.26-5.00 with the category of "Good" water quality. SIGNAL 2 analysis for Batujai Reservoir macroinvertebrates showed a value of 5.73 which categorized Batujai Reservoir as a good habitat.

Keywords: macrobenthic, bioindicator, pollution, Batujai Reservoir

\section{PENDAHULUAN}

Waduk Batujai merupakan salah satu waduk yang ada di Kabupaten Lombok Tengah. Waduk ini mulai beroperasi pada tahun 1982 dan dibangun dengan tujuan untuk menampung kelebihan air pada musim penghujan serta digunakan secara periodik untuk mengairi lahan pertanian di beberapa 
desa di sekitarnya. Desa tersebut antara lain Penujak, Setanggor, Darek, Ungga, Ranggagata, dan desa-desa lain di sekitar Kecamatan Praya Barat seluas 3.350 ha, serta untuk pembangkit listrik tenaga mikrohidro dengan daya maksimum terpasang sebesar $150 \mathrm{KW}$ [1]. Potensi tersebut menjadikan Waduk Batujai sebagai sumber pengairan yang penting di Pulau Lombok.

Waduk Batujai juga merupakan penampung beberapa aliran sungai yang ada di Lombok Tengah. Fungsi tersebut menjadikan Waduk Batujai menjadi tempat penumpukan berbagai bentuk bahan pencemar yang terbawa oleh sungai-sungai inletnya [2]. Hal tersebut dapat mengancam kelangsungan Waduk Batujai sebagai kawasan perlindungan dan rehabilitasi ekosistem yang telah direncanakan dalam Rencana Tata Ruang Wilayah Kabupaten Lombok Tengah Tahun 2011-2031. Keberlanjutan suatu kawasan perlindungan sangat ditentukan oleh tiga faktor penting yaitu faktor lingkungan, sosial dan ekonomi suatu kawasan [3]. Faktor terpenting adalah faktor lingkungan yang ditandai dengan keseimbangan ekosistem suatu kawasan yang dinamis. keseimbangan di dalam ekosistem khususnya ekosistem akuatik. Makroinvertebrata merupakan organisme tak bertulang belakang yang mendiami dasar laut dan sungai biasanya hidup menempel pada air dan lumpur. Selain itu, organisme tersebut dapat menggambarkan kondisi fisik, kimia, dan biologi perairan sehingga dapat digunakan sebagai indikator kualitas perairan [4].

Penelitian ini bertujuan untuk mengetahui keanekaragaman makroinvertebrata yang hidup di Waduk Batujai, serta mengetahui hubungan keanekaragaman jenis makroinvertebrata dengan kualitas perairan di Waduk Batujai untuk mendukung keberlanjutannya sebagai kawasan perlindungan dan rehabilitasi.

\section{METODE PENELITIAN}

Penelitan ini dilaksanakan pada bulan Juni hingga Juli 2018. Pengambilan sampel makroinvertebrata dilakukan di Waduk Batujai (Gambar 1), Desa Batujai Kecamatan Praya Barat Kabupaten Lombok Tengah, Provinsi Nusa Tenggara Barat. Sampel yang diambil adalah beberapa jenis makroinvertebrata yang hidup di sekitar Waduk Batujai.

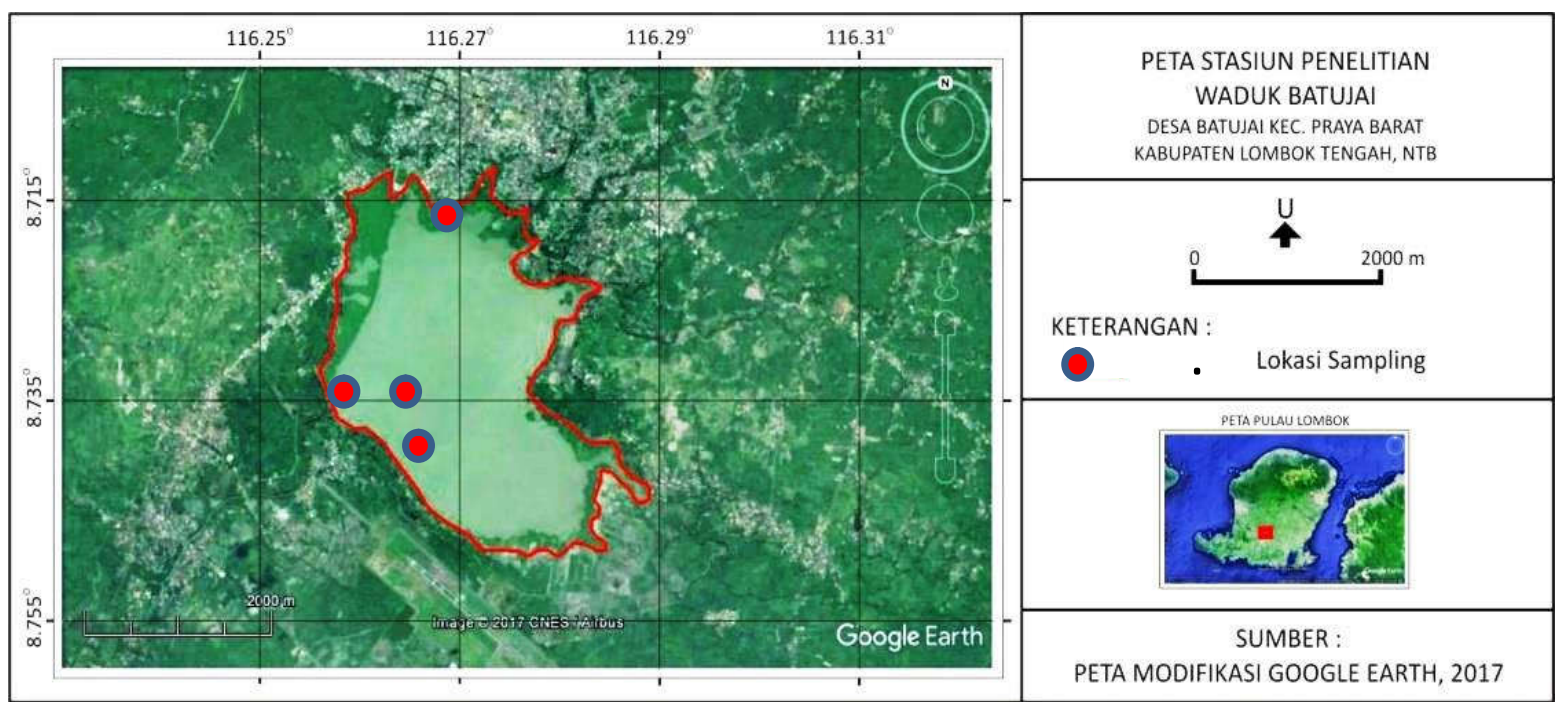

Gambar 1. Peta lokasi pengambilan sampel

Keseimbangan suatu ekosistem akan terjadi apabila komponen-komponennya dalam jumlah yang berimbang. Komponenkomponen ekosistem mencakup: faktor abiotik, produsen, konsumen, detritivora, dan dekomposer (pengurai).

Makroinvertebrata merupakan salah satu konsumen dalam rantai makanan sehingga keberadaannya sangat memengaruhi
Pengambilan contoh makroinvertebrata bentik pada permukaan air dilakukan dengan menggunakan jala atau jaring dengan ukuran bukaan $30 \times 30 \mathrm{~cm}^{2}$, diletakkan dengan menghadap arah datangnya arus. Sementara itu, untuk organisme di dasar perairan sekitar waduk, pengambilan contoh dilakukan dengan menangkap langsung (hand sampling) atau menggunakan jala surber, serta dengan 
menggunakan Ekman Grab pada makroinvertebrata yang hidup di substrat berpasir/berlumpur. Untuk mengetahui kualitas perairan, data fisik dan kimia perairan juga diamati yang meliputi suhu, salinitas, kecerahan, dan $\mathrm{pH}$.

Sampel makroinvertebrata yang dikoleksi diawetkan menggunakan formalin $4 \%$ yang dipreparasi dengan alkohol 90\%. Sampel yang telah diawetkan selanjutnya diidentifikasi di Laboratorium Dasar Universitas 45 Mataram dengan menggunakan mikroskop, dan jenis makroinvertebrata yang teridentifikasi mengacu pada [5-8].

Data yang didapatkan dianalisis menggunakan beberapa indeks yaitu indeks keanekaragaman Shannon Wiener [9], indeks keseragaman [10], indeks dominansi, Family Biotic index (FBI) [11], dan Stream Invertebrate Grade Number Average Level 2 (SIGNAL 2) [12]. Tahapan dalam menentukan nilai SIGNAL 2 meliputi: 1) Identifikasi jenis macrozoobenthos yang ditemukan hingga level famili atau level ordo, kemudian diberi skor 1 10 berdasarkan penetapan jenis famili yang ditemukan; 2) Penentuan faktor pembobotan dari jumlah individu yang ditemukan pada tiap famili dari macrozoobenthos yang ditemukan; 3) Nilai faktor pembobotan yang telah dihitung dikalikan dengan skor dari tiap famili yang ditemukan, kemudian hasil perkalian tersebut dijumlahkan secara keseluruhan; 4) Hasil penjumlahan perkalian tersebut dibagi dengan jumlah total faktor pembobotan, dan didapatkan nilai SIGNAL 2 yang biasanya berkisar antara 3-7; 5) Nilai SIGNAL 2 yang didapatkan diplotkan dalam grafik yang dihubungkan dengan jumlah famili yang ditemukan; 9) Dari grafik tersebut diperkirakan keberadaan nilai SIGNAL 2 tersebut dalam suatu kuadran. Penentuan kuadran berdasarkan pada keadaan geografis dari tempat pengambilan sampel macrozoobenthos. Dari kuadran yang diperoleh dapat diketahui kriteria lingkungannya [12].

\section{HASIL DAN PEMBAHASAN}

Keanekaragaman makrofauna akuatik di Waduk Batujai. Dari hasil penelitian ini, makroinvertebrata yang dapat teridentifikasi sebanyak 495 individu berasal dari 19 spesies dalam 10 famili yang berbeda (Tabel 1). Makroinvertebrata tersebut didapatkan pada tiga lokasi sampling yang berbeda.
Tabel 1. Keragaman dan kelimpahan makrofauna akuatik di Waduk Batujai

\begin{tabular}{|c|c|c|}
\hline Famili & Nama Spesies & $\begin{array}{l}\text { Jumlah } \\
\text { individu }\end{array}$ \\
\hline \multirow[t]{2}{*}{ Ampullariidae } & Marisa sp. & 30 \\
\hline & $\begin{array}{l}\text { Pomacea } \\
\text { canaliculata }\end{array}$ & 12 \\
\hline \multirow[t]{4}{*}{ Coenagrionidae } & $\begin{array}{l}\text { Ischnura } \\
\text { senegalensis }\end{array}$ & 3 \\
\hline & Ischnura sp. 1 & 2 \\
\hline & Ischnura sp. 2 & 3 \\
\hline & Ischnura sp. 3 & 3 \\
\hline Gerridae & Limnogonus sp. & 10 \\
\hline \multirow[t]{6}{*}{ Libellulidae } & $\begin{array}{l}\text { Brachythemis } \\
\text { contaminata }\end{array}$ & 71 \\
\hline & $\begin{array}{l}\text { Diplacodes } \\
\text { trivialis }\end{array}$ & 6 \\
\hline & $\begin{array}{l}\text { Acisoma } \\
\text { panorpoides }\end{array}$ & 12 \\
\hline & $\begin{array}{l}\text { Crocothemis } \\
\text { servilia }\end{array}$ & 3 \\
\hline & Orthetrum sabina & 5 \\
\hline & $\begin{array}{l}\text { Orthetrum } \\
\text { glaucum }\end{array}$ & 2 \\
\hline Loricariidae & $\begin{array}{l}\text { Pterygoplichthys } \\
\text { disjunctivus }\end{array}$ & 87 \\
\hline Notonectidae & Anisops breddini & 140 \\
\hline Palaemonidae & $\begin{array}{l}\text { Macrobrachium } \\
\text { lar }\end{array}$ & 33 \\
\hline Parastacidae & $\begin{array}{l}\text { Cherax } \\
\text { quadricarinatus }\end{array}$ & 7 \\
\hline Thiaridae & Tarebia granifera & 21 \\
\hline Unionidae & $\begin{array}{l}\text { Pilsbryoconcha } \\
\text { exilis }\end{array}$ & 45 \\
\hline \multicolumn{2}{|c|}{ Total Individu } & 495 \\
\hline
\end{tabular}

Dari 19 spesies tersebut salah satu spesies yang memiliki kelimpahan tertinggi yaitu Anisops breddini (kumbang air). Spesies ini hampir ditemukan di setiap lokasi pengambilan sampel. Sementara itu, yang memiliki kelimpahan paling sedikit ada dua yaitu Orthetrum glaucum dan Ishnura sp.1.

Tingkat keanekaragaman jenis makroinvertebrata akuatik di Waduk Batujai masuk dalam kategori sedang. Hal tersebut terlihat dari hasil perhitungan indeks keanekaragaman Shanon-Wiener $\left(H^{\prime}\right)$ sebesar 2,42. Nilai keanekaragaman tersebut diikuti oleh nilai keseragaman $(E)$ sebesar 0,76 . Nilai keseragaman tersebut mendekati angka 1 dan masuk kategori keseragaman tinggi yang 
artinya sebaran individu antarjenis di perairan cukup merata atau dapat dikatakan tidak ada spesies tertentu yang sangat mendominasi. Hal tersebut juga dapat dilihat dari hasil perhitungan indeks dominansi (C) sebesar 0,12 yang mengindikasikan perairan Waduk Batujai tidak didominasi oleh spesies tertentu karena nilai indeks dominansi mendekati angka nol. Barus [13] menyatakan bahwa suatu wilayah perairan yang memiliki tingkat pencemaran tinggi akan mengakibatkan persebaran keberadaan individu dari organisme tertentu menjadi tidak merata dan akan ada yang mendominasi.

Hasil penelitian ini juga menunjukkan bahwa kelompok hewan terbanyak dan paling merata keberadaanya adalah Filum Arthropoda. Anggota Filum Arthropoda dalam penelitian ini dikelompokkan ke dalam enam famili yaitu Coenagrionidae, Gerridae, Libellulidae, Notonectidae, Palaemonidae, dan Parastacidae. Arthropoda merupakan kelompok hewan dengan keragaman dan kelimpahan tertinggi di bumi [14]. Arthropoda yang tertangkap dalam penelitian ini ada yang hidup di dasar perairan dan ada yang memanfaatkan bagian permukaan perairan. Arthropoda yang hidup di dasar perairan adalah famili Palaemonidae dan Parastacidae yang masing-masing merupakan spesies udang galah dan lobster air tawar. Arthropoda yang hidup di permukaan perairan masuk ke dalam famili Coenagrionidae, Gerridae, Libellulidae, dan Notonectidae yang masing-masing merupakan spesies capung dan kumbang air.

\footnotetext{
Kualitas perairan Waduk Batujai ditinjau dari keanekaragaman makrofauna akuatik. Waduk Batujai memiliki tiga sungai inlet utama yang menjadi sumber pengairannya yaitu Sungai Leneng, Sungai Sade/ Tiwubare, dan Sungai Dodokan/ Srigangga/ Surabaya. Ketiga sungai tersebut membawa sejumlah besar bahan organik, sedimen, dan bahan pencemar dari daerah hulu dan sepanjang aliran sungai [2]. Kualitas air sungai yang masuk ke Waduk Batujai tercemar oleh pencemar organik hal ini terlihat dengan kualitas airnya seperti BOD, COD cukup tinggi yaitu dengan nilai masing-masing berkisar antara $2,4 \square 3,7 \mathrm{mg} / \mathrm{L}$ dan $12 \square 12,5 \mathrm{mg} / \mathrm{L} \mathrm{[15].} \mathrm{Nilai} \mathrm{tersebut} \mathrm{sudah}$ tidak layak untuk sumber baku air minum karena sudah melebihi kelas 1, PP 82/2001.

Makroinvertebrata akuatik juga dapat
}

dijadikan salah satu indikator tingkat pencemaran air. Salah satu kelompok hewan yang dapat dijadikan parameter tingkat pencemaran air adalah kelompok serangga air [16]. Dari hasil penelitian yang telah dilakukan diketahui bahwa Waduk Batujai memiliki banyak jenis serangga air yang memiliki nilai pembobotan tertentu terhadap tingkat pencemaran di ekosistem perairan.

Nilai tersebut sangat tergantung kepada tingkat toleransi masing-masing famili. Hasil perhitungan nilai pembobotan tersebut selanjutnya dapat dikonversi menjadi kualitas ekosistem perairan dimana hewan itu tinggal. Makrofauna akuatik yang ada di Waduk Batujai memperlihatkan nilai Family Biotic Index (FBI) sebesar 4,73. Nilai tersebut berada di kisaran 4,26-5,00 dengan kategori kualitas air yang "Baik". Menurut Hilsenhoff [11], kategori tersebut masih mungkin memiliki beberapa bentuk pencemaran dari polutan organik. Kondisi tersebut sangat mungkin terjadi karena Waduk Batujai merupakan penampungan tiga sungai besar yang ada di Lombok Tengah. Sungai tersebut melewati pemukiman warga yang merupakan sumber utama polutan organik yang masuk ke Waduk Batujai. Polutan organik juga dapat berasal dari sisa pupuk yang mengalir melalui saluran irigasi persawahan yang mengelilingi Waduk Batujai.

Keberadaan makroinvertebrata sangat penting dalam usaha pengkajian kondisi habitat perairan. Penelitian ini menggunakan analisis SIGNAL 2 (Stream Invertebrate Grade Number Average Level 2) untuk mengkategorikan habitat perairan makroinvertebrata yang hidup di dalamnya. Analisis SIGNAL 2 untuk makroinvertebrata Waduk Batujai menunjukkan nilai sebesar 5,73 yang mengkategorikan Waduk Batujai sebagai habitat yang baik dan sedikit gangguan (Gambar 2). Menurut Chessman [12], apabila skor SIGNAL 2 semakin kecil, hal ini menunjukan organisme memiliki toleransi tinggi terhadap kondisi lingkungan tercemar. 


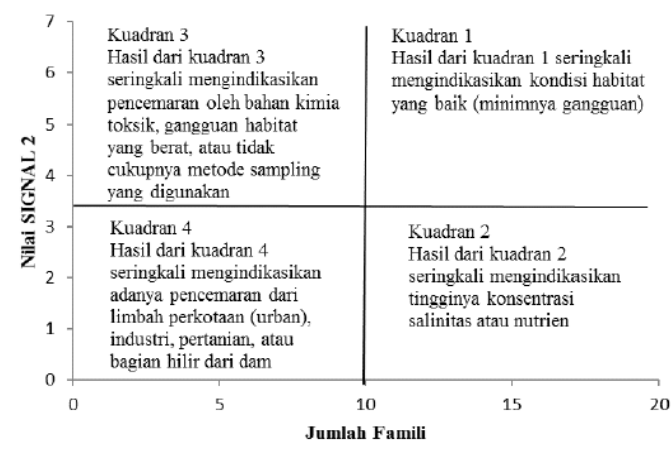

Gambar 2. Grafik pengkategorian habitat analisis SIGNAL 2

\section{KESIMPULAN}

Berdasarkan hasil analisis kualitas air di Waduk Batujai Lombok Tengah diketahui bahwa perairan di daerah ini memiliki bentuk pencemaran dari polutan organik yang ringan yang dilihat dari nilai FBI yang kecil sehingga tidak memengaruhi keberadaan dan keanekaragaman jenis makroinvertebrata air di sekitarnya.

\section{UCAPAN TERIMA KASIH}

Ucapan terimakasih diberikan kepada Kemenristekdikti yang telah mendanai penelitian ini melalui skema Penelitian Dosen Pemula Tahun 2017/2018. Terimakasih pula diberikan kepada Mashur, Vitalis Nangkung, Kusumawardani dan para nelayan yang telah membantu pelaksanaan penelitian ini hingga selesai.

\section{DAFTAR PUSTAKA}

[1] Raiz FJ (2013) Bendungan Batujai. Kementerian Pekerjaan Umum, Dirjen Sumber daya Air, Balai Wilayah Sungai NT 1, Indonesia.

[2] Achmad F (2011) Dampak pencemaran lingkungan kota praya terhadap kualitas air Waduk Batujai. Buletin Geologi Tata Lingkungan 21(2): 69 - 82.

[3] Prasasti BG, Basuni S, Sunarminto T (2016) Analisis faktor penentu keberlanjutan dan strategi pemanfaatan lahan di Lokapurna Taman Nasional Gunung Halimun Salak. Media Konservasi 21(3): 286-294.

[4] Rahayu S, Widodo RH, van Noordwijk M, Suryadi I, Verbist B (2009) Monitoring air di daerah aliran sungai. World Agroforestry Centre-Southeast
Asia Regional Office, Bogor, Indonesia, 104 hal.

[5] Borror DJ, Triplehorn DJ, Johnson NF (1996) An Introduction of the study of insects. Saunders College Pub., New York.

[6] Bouchard RW (2004) Guide to the aquatic macroinvertebrates of the upper midwest. University of Minessota.

[7] Jessup BK, Markowitz A, Stribling JB, Friedman E, LaBelle K, Dziepak N (2003) Family level key to the stream invertebrates of Maryland and surrounding areas. Third edition, Maryland Department of Natural Resources. Maryland.

[8] Subyanto, Sulhotoni A (1991) Kunci determinasi serangga. Kanisius, Yogyakarta.

[9] Krebs CJ (1999) Ecological methodology. Second edition. AddisonWesley Educational Publishers, Inc., Menlo Park, California.

[10] Odum EP (1993) Dasar-dasar ekologi (penerjemah Tjahjono Samingan; penyunting B. Srigandono). Gadjah Mada University Press, Yogyakarta.

[11] Hilsenhoff WL (1987) An improved biotic index of organic stream pollution. The Great Lakes Entomologist 20(1): 31-39.

[12] Chessman B (2003) SIGNAL 2 - A Scoring system for macro-invertebrate ('Water Bugs') in Australian Rivers, Monitoring river heath initiative technical report no 31. Commonwealth of Australia, Canberra.

[13] Barus TA (2002) Pengantar limnologi. Dirjen Pendidikan Tinggi, Medan.

[14] Leksono AS (2017) Ekologi arthropoda. UB Press, Malang.

[15] Brahmana, Simon S, Achmad F, Sumarriani Y (2010) Pencemaran nutrien (zat hara) dan kualitas air waduk kaskade Batujai dan Pengga di Pulau Lombok. Jurnal Sumber Daya Air 6(1): 75 - 86.

[16] Leba GV, Koneria R, Papu A (2013) Keanekaragaman serangga air di Sungai Pajowa Kabupaten Minahasa, Sulawesi Utara. Jurnal MIPA Unsrat Online 2(2): 73-78. 